\title{
Characteristics of an adenylate cyclase enhancing factor from mouse pancreatic islet cytosol
}

\author{
P.Thams, K. Capito and C.J.Hedeskov \\ Department of Biochemistry A, University of Copenhagen, Copenhagen, Denmark
}

Summary. The role of cytosolic components in the regulation of mouse pancreatic islet adenylate cyclase activity was studied. Addition of mouse islet cytosol $(27000 \mathrm{~g}$ supernatant of mouse islet sonicate), devoid of adenylate cyclase activity itself, increased adenylate cyclase activity by $93 \pm 17 \%(n=9)$ in the $27000 \mathrm{~g}$ total particulate fraction of mouse islets. Addition of GTP stimulated adenylate cyclase activity by $91 \pm 11 \%$ $(n=13)$ or to the same degree as cytosol. Like GTP, the substance causing the enhancing activity of the cytosol was found to be dialysable, resistant to heat, sensitive to charcoal treatment and alkaline phosphatase and insensitive to digestion with trypsin. However, in contrast to the stimulation by GTP, the stimulation by cytosol was not inhibited by guanosine 5'-0-(2-thiodiphosphate), and furthermore, the effects of cytosol and GTP were additive. Neither NAD nor phosphoenolpyruvate stimulated adenylate cyclase activity. The cytosolic factor did not confer sensitivity towards glucose, $\mathrm{Ca}^{2+}$ or $\mathrm{Ca}^{2+}$-calmodulin on adenylate cyclase. The results demonstrate that mouse pancreatic islets contain a phosphocompound (or several compounds) distinct from GTP and capable of markedly stimulating adenylate cyclase. The identity of the compound and its physiological significance remain to be established.

Key words: Adenylate cyclase, cytosol, pancreatic islets, mouse.
The adenylate cyclase system (ATP pyrophosphate lyase (cyclizing) EC 4.6.1.1.) is a key factor in the action of many different hormones. Major components of the hormonal machinery located in the plasma membrane include the hormone receptor, the guanine nucleotide regulatory unit, and the adenylate cyclase enzyme itself [1]. The most widely recognized endogenous regulator of adenylate cyclase is the guanine nucleotide, GTP, which has been shown to be an absolute requirement for the expression of hormone-sensitive adenylate cyclase activity in many different tissues [1]. Beside the guanine nucleotides, a number of other cytosol-derived factors, usually not identified, have been implicated as potential intracellular regulators of several adenylate cyclases [2-8].

A recent study dealing with the effects of $\mathrm{Ca}^{2+}$ and calmodulin on pancreatic islet adenylate cyclase [9] led us to prepare EGTA-washed particulate fractions of mouse and rat pancreatic islets. During preparation of particulate fractions, a loss in adenylate cyclase activity was observed when compared with whole homogenates and which, by analogy with similar observations in a number of other tissue preparations [2-8], might be explained by the removal of cytosolic factors capable of stimulating adenylate cyclase. In the present report, we describe the experiments which demonstrate (1) activation of mouse pancreatic islet adenylate cyclase by islet cytosol, and (2) preliminary characteristics of the cytosolic activator(s) in comparison with GTP.

\section{Materials and methods}

\section{Materials}

Crude bacterial collagenase, creatine kinase, phosphocreatine, cyclic AMP, GTP, guanosine $5^{\prime}$ - $(\beta, \gamma$-imino)triphosphate (GMPPNP), guanosine $5^{\prime}-0$-(2-thiodiphosphate) (GDP- $\beta$-S), and alkaline phosphatase were obtained from Boehringer, Mannheim, FRG. 2-((2-hydroxy-1-1,-bis-(hydroxymethyl)-ethyl)-amino)ethanesulphonic acid (Tes buffer), ethylene glycol bis- $\left(\beta\right.$-aminoethyl ether)- $\mathrm{N}, \mathrm{N}, \mathrm{N}^{\prime}, \mathrm{N}^{\prime},-$ tetraacetic acid (EGTA), activated charcoal and ATP (A2383) were purchased from Sigma Chemicals, St. Louis, MO, USA. Nitrilotriacetic acid (NTA) was obtained from E. Merck, Darmstadt, FRG. 3-isobutyl-1-methylxanthine (IBMX) was from EGA-Chemie, Steinheim/ Albuch, FRG. Human serum albumin was from Behringswerke, Marburg, FRG. Dextran T100 was from Pharmacia, Uppsala, Sweden.

All other chemicals were of analytical grade obtained from ordinary commercial sources. 
Table 1. Effect of cytosol on adenylate cyclase activity

\begin{tabular}{|c|c|c|c|}
\hline Added agents & $\begin{array}{l}\text { Activity } \\
\text { ( } \% \text { of } \\
\text { control) }\end{array}$ & $\begin{array}{l}\text { Number } \\
\text { of experi- } \\
\text { ments }\end{array}$ & $\begin{array}{l}p \text { (versus } \\
\text { control) }\end{array}$ \\
\hline Nil & 100 & & \\
\hline Cytosol & $193 \pm 17$ & 9 & $<0.001$ \\
\hline Heated cytosol & $184 \pm 8$ & 12 & $<0.001$ \\
\hline Dialysed cytosol & $118 \pm 9$ & 5 & NS \\
\hline $\mathrm{GTP}(10 \mu \mathrm{mol} / \mathrm{l})$ & $191 \pm 11$ & 13 & $<0.001$ \\
\hline GTP $(10 \mu \mathrm{mol} / 1)+$ cytosol & $263 \pm 25$ & 7 & $\begin{array}{l}<0.001 \\
<0.02^{\mathrm{a}}\end{array}$ \\
\hline $\begin{array}{l}\text { Phosphatase-treated } \\
\text { heated cytosol }\end{array}$ & $105 \pm 5$ & 6 & NS \\
\hline $\begin{array}{l}\text { Charcoal-treated } \\
\text { heated cytosol }\end{array}$ & $104 \pm 3$ & 4 & NS \\
\hline $\begin{array}{l}\text { Phosphatase-treated } \\
\text { GTP }(10 \mu \mathrm{mol} / \mathrm{l})\end{array}$ & $109 \pm 2$ & 5 & $<0.02$ \\
\hline $\begin{array}{l}\text { Charcoal-treated } \\
\text { GTP }(10 \mu \mathrm{mol} / 1)\end{array}$ & $105 \pm 8$ & 4 & NS \\
\hline $\begin{array}{l}\text { GTP }(10 \mu \mathrm{mol} / 1) \\
\quad+\text { phosphatase-treated } \\
\text { heated cytosol }\end{array}$ & $185 \pm 5$ & 4 & $\mathrm{NS}^{\mathrm{a}}$ \\
\hline
\end{tabular}

Results are given as mean \pm SEM of the control value $(617 \pm 54 \mathrm{pmol}$; $n=19$ ) of cyclic AMP/ $60 \mathrm{~min}$ per mg islet particulate protein.

a Versus GTP-stimulated activity

\section{Preparation of islets}

Islets were prepared by collagenase digestion [10] of the pancreases of male albino mice (approximately $26 \mathrm{~g}$ weight) fed ad libitum on a standard laboratory diet.

\section{Preparation of islet particulate and soluble fractions}

A group of 500 islets was collected in 125-250 $\mu$ l of Tes buffer (25 mmol/1; pH 7.6) containing $\mathrm{MgCl}_{2}(5 \mathrm{mmol} / 1)$, and EGTA $(1 \mathrm{mmol} / \mathrm{l})$. A homogenate was prepared by sonication $(10 \mathrm{~s}, 40 \mathrm{~W})$. The homogenate was centrifuged for $20 \mathrm{~min}$ at $27000 \mathrm{~g}$ at $4^{\circ} \mathrm{C}$. The supernatant (cytosol) was retained for later use and the pellet was resuspended and centrifuged twice more in $500 \mu l$ of the same Tes buffer. After the last centrifugation and resuspension, the particulate fraction and the cytosol were frozen in liquid $\mathrm{N}_{2}$ and stored at $-80^{\circ} \mathrm{C}$ until the next day. Protein was measured with bovine serum albumin as standard as described by Groves et al. [11].

\section{Assay of adenylate cyclase}

The assay was based on that described previously [9]. The reaction mixture $(80 \mu \mathrm{l})$ contained ATP $(3 \mathrm{mmol} / \mathrm{l}), \operatorname{IBMX}(1 \mathrm{mmol} / \mathrm{l}), 0.15 \%$ human serum albumin, NTA ( $20 \mathrm{mmol} / 1)$, EGTA ( $1 \mathrm{mmol} / 1), \mathrm{MgCl}_{2}$ $(26.7 \mathrm{mmol} / \mathrm{l})$, Tes buffer $(25 \mathrm{mmol} / 1 ; \mathrm{pH} 7.6)$, phosphocreatine $(5 \mathrm{mmol} / \mathrm{l}), 0.5 \mathrm{mg}$ of creatine kinase $/ \mathrm{ml}, 3-4 \mu \mathrm{g}$ of islet particulate protein (corresponding to 10 islets), with or without $10 \mu \mathrm{l}$ of islet cytosol or treated cytosol (corresponding to 20 islets) and further additions as indicated in the tables. The reaction was carried out at $30^{\circ} \mathrm{C}$ for $60 \mathrm{~min}$ and terminated by heating at $95^{\circ} \mathrm{C}$ for $3 \mathrm{~min}$. After cooling, $60 \mu \mathrm{l}$ of $\mathrm{ZnSO}_{4}(0.4 \mathrm{~mol} / 1)$ and $60 \mu \mathrm{l}$ of $\mathrm{Na}_{2} \mathrm{CO}_{3}(0.4 \mathrm{~mol} / \mathrm{l})$ were added for precipitation of ATP. After centrifugation at $6000 \mathrm{~g}$ for $10 \mathrm{~min}$, the supernatants were stored at $-20^{\circ} \mathrm{C}$ until assayed for cyclic AMP. The activity was proportional to the amount of islet particulate protein and was linear with time for at least $75 \mathrm{~min}$ in all experimental conditions tested. Cyclic AMP was measured by a competitive protein binding assay [12]. Neither cytosol nor other components in the adenylate cyclase assay interfered with this assay. Thus the average recovery of $2 \mathrm{pmol}$ of cyclic AMP added to the incubate after heat inactivation was $98 \pm 4 \%(n=3)$ in control samples and $100 \pm 8 \%$ $(n=3)$ in samples incubated with cytosol.

\section{Treatment of cytosol}

Dialysis: Cytosol $(100 \mu \mathrm{l})$ was dialysed at $4{ }^{\circ} \mathrm{C}$ for $18 \mathrm{~h}$ against $150 \mathrm{ml}$ of Tes buffer ( $25 \mathrm{mmol} / 1 ; \mathrm{pH} 7.6)$ containing $\mathrm{MgCl}_{2}(5 \mathrm{mmol} / 1)$, and EGTA $(1 \mathrm{mmol} / \mathrm{l})$.

Heat: Cytosol $(100-200 \mu 1)$ was heated to $95^{\circ} \mathrm{C}$ for $5 \mathrm{~min}$. Denatured material was removed by centrifugation at $6000 \mathrm{~g}$ for $10 \mathrm{~min}$.

Alkaline phosphatase: Heated cytosol, GTP solution or buffer $(100 \mu \mathrm{l})$ were incubated at $37^{\circ} \mathrm{C}$ for $30 \mathrm{~min}$ with $10 \mu \mathrm{l}$ (2 units) of alkaline phosphatase in Tes buffer $\left(25 \mathrm{mmol} / 1\right.$; pH 7.6) containing $\mathrm{MgCl}_{2}$ $(5 \mathrm{mmol} / \mathrm{l})$, and EGTA $(1 \mathrm{mmol} / 1)$. The reaction was terminated by heating at $95^{\circ} \mathrm{C}$ for 5 min after which the samples were centrifuged at $6000 \mathrm{~g}$ for $10 \mathrm{~min}$. Control incubations at $37^{\circ} \mathrm{C}$ of heated cytosol, GTP or buffer were carried out with heated alkaline phosphatase. Charcoal: A mixture of $100 \mathrm{mg}$ charcoal, $10 \mathrm{mg}$ human serum albumin, and $10 \mathrm{mg}$ Dextran T100 was prepared in $1 \mathrm{ml}$ of Tes buffer (25 mmol/1; $\mathrm{pH} 7.6)$ containing $\mathrm{MgCl}_{2}(5 \mathrm{mmol} / \mathrm{l})$, and EGTA $(1 \mathrm{mmol} / \mathrm{l})$. Portions $(20 \mu \mathrm{l})$ of the charcoal suspension were centrifuged at $6000 \mathrm{~g}$ for $10 \mathrm{~min}$. The resultant supernatants were removed and $50 \mu \mathrm{l}$ samples of heated cytosol, GTP or buffer were added to the charcoal pellets and mixed thoroughly. The samples were then centrifuged to separate the charcoal from the treated samples.

\section{Expression of results}

Results are given as mean \pm SEM with $n=$ number of experiments. Statistical evaluation of the data was made by Student's paired t-test. NS $=$ not significant $(p>0.05)$.

\section{Results}

\section{Effect of cytosol on adenylate cyclase activity}

Addition of cytosol (27000 $\mathrm{g}$ supernatant of mouse islet sonicate) devoid of adenylate cyclase activity itself increased the particulate adenylate cyclase activity $93 \pm$ $17 \%(n=9)$ above controls (Table 1). This maximal stimulation was obtained upon addition of cytosol corresponding to 20 islets. The cytosol dependence of the activity exhibited saturation kinetics with half-maximum stimulation obtained by addition of cytosol corresponding to approximately five islets (not shown). Double-reciprocal plots of the adenylate cyclase activity versus the ATP concentration revealed that the cytosol increased the $V_{\max }$ of the enzyme without affecting the apparent $\mathrm{K}_{\mathrm{m}}$ for $\operatorname{ATP}(117 \pm 3 \mu \mathrm{mol} / \mathrm{l}, n=4)$.

The stimulatory effect of the cytosol was retained after heating but lost upon dialysis of the cytosol (Table 1). GTP at $10 \mu \mathrm{mol} / 1$, which was a maximum stimulating concentration, increased the adenylate cyclase activity $91 \pm 11 \%(n=13)$ above controls or to the same degree as cytosol. In combination GTP $(10 \mu \mathrm{mol} / \mathrm{l})$ and cytosol increased the activity $163 \pm 25 \%$ $(n=7)$ above control values. The stimulatory effect of cytosol was not significantly affected by the presence of GTP. Thus, in the presence of GTP the activity due to cytosol was $65 \pm 19 \%(n=7)$ of controls without GTP and cytosol. These results suggest that the cytosolic effect should not solely be attributed to GTP. 


\section{Effect of alkaline phosphatase and charcoal}

The adenylate cyclase-enhancing activity of the cytosol was sensitive to alkaline phosphatase digestion (Table 1). Exposure under the conditions described caused a total abolition of the enhancing activity of the cytosol. Similarly, exposure to charcoal totally abolished the capacity of cytosol to stimulate adenylate cyclase, suggesting that the stimulation might be dependent on endogenous GTP. However, GTP $(10 \mu \mathrm{mol} / 1)$ failed to re-establish the combined effect of GTP $(10 \mu \mathrm{mol} / \mathrm{l})$ and cytosol when added to the phosphatase-treated cytosol (Table 1). Glucagon is dialysable, heat-stable and dependent on GTP for stimulation of adenylate cyclase and therefore would be a likely candidate in a preparation of pancreatic islet cytosol. However, it did not seem to be present in sufficient concentration in the cytosol preparation to stimulate adenylate cyclase, since both trypsin and glucagon antiserum failed to affect the ability of cytosol to stimulate adenylate cyclase (not shown).

\section{Effect of quanosine 5'-0-(2-thiodiphosphate)}

To confirm the separate effects of cytosol and GTP on adenylate cyclase, we took advantage of the availability of the GDP analogue GDP- $\beta$-S. GDP- $\beta$-S has been shown to be resistant to hydrolysis and phosphorylation by a number of membrane preparations and to inhibit GTP- and hormone-stimulation of adenylate cyclase [3, $13,14]$. In mouse islet particulate fractions GDP- $\beta$-S $(1 \mathrm{mmol} / \mathrm{l})$ stimulated basal adenylate cyclase activity $(60 \pm 6 \%, n=5$; Table 2). The nature of this stimulation is not clear. A conversion of GDP- $\beta$-S to the stimulatory guanosine triphosphate form seems unlikely, since these experiments were performed in the absence of creatine kinase and phosphocreatine [13], and since the adenylate cyclase activity in the presence of GDP- $\beta$-S was linear with time throughout the incubation period (not shown). However, GDP- $\beta$-S $(1 \mathrm{mmol} / 1)$ totally prevented stimulation by GTP $(10 \mu \mathrm{mol} / 1)$ or GMPPNP $(10 \mu \mathrm{mol} / \mathrm{l})$, but did not affect the stimulation by heated cytosol. Thus, in the presence of GDP- $\beta$-S the activity due to heated cytosol was $72 \pm 17 \%(n=5)$ of control values without GDP- $\beta$-S and heated cytosol. GDP- $\beta$-S did not restore the combined effect of GDP- $\beta$-S and heated cytosol when $1 \mathrm{mmol} / 1$ of GDP- $\beta$-S was added to phosphatase-treated cytosol (not shown).

\section{Further characteristics of the cytosolic factor}

The results suggest that pancreatic islets contain a phosphocompound distinct from GTP and capable of markedly stimulating adenylate cyclase. NAD and phosphoenolpyruvate have been shown to stimulate adenylate cyclase under certain conditions $[15,16]$. However, neither NAD nor phosphoenolpyruvate stimulated the adenylate cyclase activity in the absence or presence of cytosol, phosphatase-treated cytosol, GTP or GTP plus
Table 2. Effect of GDP- $\beta$-S on the ability of heated cytosol to enhance adenylate cyclase activity

\begin{tabular}{|c|c|c|c|}
\hline Added agents & $\begin{array}{l}\text { Activity } \\
\text { ( } \% \text { of } \\
\text { control) }\end{array}$ & $\begin{array}{l}\text { Number } \\
\text { of experi- } \\
\text { ments }\end{array}$ & $\begin{array}{l}p \text { (versus } \\
\text { control) }\end{array}$ \\
\hline Nil & 100 & & \\
\hline Heated cytosol & $198 \pm 23$ & 5 & $<0.01$ \\
\hline GTP $(10 \mu \mathrm{mol} / 1)$ & $194 \pm 19$ & 5 & $<0.005$ \\
\hline GMPPNP $(10 \mu \mathrm{mol} / 1)$ & $823 \pm 111$ & 3 & \\
\hline GDP- $\beta-\mathrm{S}(1 \mathrm{mmol} / \mathrm{l})$ & $160 \pm 6$ & 5 & $\begin{array}{l}<0.001 \\
<0.05^{a}\end{array}$ \\
\hline $\begin{array}{l}\text { GDP- } \beta \text {-S }(1 \mathrm{mmol} / 1) \\
+ \text { heated cytosol }\end{array}$ & $232 \pm 17$ & 5 & $<0.01^{\mathrm{b}}$ \\
\hline $\begin{array}{l}\text { GDP- } \beta-\mathrm{S}(1 \mathrm{mmol} / 1) \\
\quad+\mathrm{GTP}(10 \mu \mathrm{mol} / \mathrm{l})\end{array}$ & $155 \pm 10$ & 5 & $\mathrm{NS}^{\mathrm{b}}$ \\
\hline $\begin{array}{l}\text { GDP- } \beta-S(1 \mathrm{mmol} / 1) \\
+ \text { GMPPNP }(10 \mu \mathrm{mol} / 1)\end{array}$ & $179 \pm 26$ & 3 & \\
\hline
\end{tabular}

Results are given as mean \pm SEM of the control value $(569 \pm 84$ pmol; $n=7$ ) of cyclic AMP/ 60 min per mg islet particulate protein. Adenylate cyclase activity was determined in the absence of creatine kinase and phosphocreatine.

${ }^{a}$ Versus GTP-stimulated activity. ${ }^{b}$ Versus GDP- $\beta$-S-stimulated activity

phosphatase-treated cytosol (not shown). The islet cytosolic factor did not confer sensitivity upon adenylate cyclase towards glucose, $\mathrm{Ca}^{2+}$ or $\mathrm{Ca}^{2+}$ plus calmodulin (not shown).

\section{Discussion}

The present findings demonstrate that pancreatic islets contain a phosphocompound (or several compounds) distinct from GTP and capable of stimulating adenylate cyclase. The preliminary characterization of this compound shows that it shares several properties with GTP and appears to be dependent on phosphate groups for stimulation. Thus it was dialysable, resistant to heat, sensitive to charcoal treatment, sensitive to treatment with alkaline phosphatase and insensitive to tryptic digestion. However, in contrast to the stimulation by GTP, the stimulation by the cytosolic factor was not inhibited by GDP- $\beta$-S, and furthermore, the effects of GTP and cytosolic factor were additive.

Cytosolic factors have recently been reported to activate adenylate cyclase or to restore hormone-responsiveness of adenylate cyclase in several tissues including rat reticulocytes, rat osteosarcoma, rat liver, pig lymphocytes and human platelets [2-7]. It is impossible to find unique properties shared by these various factors and the present pancreatic islet factor. The islet factor is heat-stable, as that of rat liver [6] and pig lymphocytes [7] while those reported for rat reticulocytes [2], rat osteosarcoma [5] and human platelets [5] are sensitive to heat treatment. The factor described in [7] is dialysable as the islet compound, but the factors in $[2,5,6]$ are not or only partially lost upon dialysis. The islet factor, as those from human platelets and rat osteosarcoma [5], is 
totally lost on exposure to alkaline phosphatase, whereas that described for rat reticulocytes [2] is insensitive to alkaline phosphatase. Like the lymphocyte factor [7] the present factor was dialysable and heat-stable, but in contrast to the lymphocyte factor, it was not bound to concanavalin A-Sepharose (results not shown).

It is well-established that glucose increases the pancreatic islet content of cyclic AMP. Furthermore, it is agreed that cyclic AMP enhances the islet $\beta$-cell insulin response [17]. However it is a matter of debate whether glucose has any direct effect on adenylate cyclase in the islets. Some evidence suggests that the raised intracellular $\mathrm{Ca}^{2+}$-concentration in response to glucose is responsible for stimulation of adenylate cyclase but, as recently reported by us, neither $\mathrm{Ca}^{2+}$ nor $\mathrm{Ca}^{2+}$ plus calmodulin stimulate mouse islet adenylate cyclase activity [9]. The cytosolic factor described in the present report was not dependent on $\mathrm{Ca}^{2+}$ for its enhancing activity and did not confer sensitivity towards glucose, $\mathrm{Ca}^{2+}$ or $\mathrm{Ca}^{2+}$ plus calmodulin upon adenylate cyclase. These results confirm our recent results obtained on whole homogenates of mouse islets [9].

The cytosolic factor appears to exist in great excess in the islets. Assuming equal distribution of the factor in the intracellular waterspace and a total waterspace of approximately $2-3 \mathrm{nl} /$ islet, the cytosolic factor was diluted 1000-2000-fold in the adenylate cyclase assay. It is conceivable that the factor is not truly cytoplasmic in origin, but is loosely bound to the inner aspect of the cell membrane and eluted from it during preparation of particulate fractions. Alternatively, the factor may be compartmentalized in the cytoplasm or between different cell types in the islets.

Only preliminary characteristics of the factor have been obtained so far and the physiological significance of the factor remains to be established. However, it is not unreasonable to speculate that it may have an important rôle in regulation of islet adenylate cyclase activity. Indeed identification of the islet factor might assist in unravelling the mechanism by which glucose increases intracellular cyclic AMP in pancreatic islets.

Acknowledgements. This work was supported by financial aid from the Danish Medical Research Council (Grant no.12-2201), Novo's Fond, Nordisk Insulinfond, P. Carl Petersens fond, Dr. med. Erik Garde og Elisabeth Garde's legat, and the Danish Diabetic Association. The skilful technical assistance of Mrs. I. Mikkelsen is highly appreciated.

\section{References}

1. Ross EM, Gilman AG (1980) Biochemical properties of hormonesensitive adenylate cyclase. Ann Rev Biochem 49: 533-564
2. Gholamhosein OR, Gammon DE, Bilezikian JP(1980) Regulation of catecholamine-responsive adenylate cyclase activity in rat reticulocyte membranes by endogenous factors. General characteristics and resolution into protein and nucleotide components. Biochim Biophys Acta 629: 455-469

3. Egan JJ, Majeska RJ, Rodan GA (1980) Osteosarcoma cytosol factor promotes parathyroid hormone stimulation of adenylate cyclase independent of GTP. Biochim Biophys Acta 632: 483-496

4. Macneil S, Crawford A, Amirrasooli H, Johnson S, Pollock A, O1lis C, Tomlinson S (1980) Stimulation of hormone-responsive adenylate cyclase activity by a factor present in the cell cytosol. Biochem J 188: 393-400

5. Crawford A, Macneil S, Amirrasooli H, Tomlinson S (1980) Properties of a factor in cytosol that enhances hormone-stimulated adenylate cyclase activity. Biochem J 188: 401-407

6. Doberska CA, Martin BR (1977) Activation of rat liver plasma membrane adenylate cyclase by a cytoplasmic protein factor. FEBS Lett 82: 273-277

7. Bonnafous J-C, Dornand J, Mani J-C (1979) Deactivation of lymphocyte adenylate cyclase by affinity chromatography on Con Asepharose. FEBS Lett 99: 152-156

8. Ofulue AF, Nijjar MS (1981) Calmodulin activation of rat lung adenylate cyclase is independent of the cytoplasmic factors modulating the enzyme. Biochem J 200: 475-480

9. Thams P, Capito K, Hedeskov CJ (1982) Differential effects of $\mathrm{Ca}^{2+}$-calmodulin on adenylate cyclase activity in mouse and rat pancreatic islets. Biochem J 206:97-102

10. Coll-Garcia E, Gill JR (1969) Insulin release by isolated pancreatic islets of the mouse incubated in vitro. Diabetologia 5:61-66

11. Groves WE, Davis FC, Milnec BH (1968) Spectrophotometric determination of microgram quantities of protein without nucleic acid interference. Anal Biochem 22: 195-210

12. Geisler A, Klysner R, Thams $P$, Christensen S (1977) A simple and inexpensive protein binding assay for cyclic AMP in biological materials. Acta Pharmacol Toxicol 40:356-368

13. Eckstein F, Cassel D, Levkovitz H, Lowe M, Selinger Z (1979) Guanosine 5'-0-(2-thiodiphosphate). An inhibitor of adenylate cyclase stimulation by guanine nucleotides and fluoride. J Biol Chem 254: 9829-9834

14. Seamon KB, Daly JW (1982) Calmodulin stimulation of adenylate cyclase in rat brain membranes does not require GTP. Life Sci 30 : 1457-1464

15. Moss J, Vaughan M (1978) Isolation of an avian erythrocyte protein possessing ADP-ribosyltransferase activity and capable of activating adenylate cyclase. Proc Natl Acad Sci USA 75: 3621-3624

16. Capito K, Hedeskov CJ (1977) Effects of glucose, glucose metabolites, and calcium ions on adenylate cyclase activity in homogenates of mouse pancreatic islets. Biochem J 162: 569-573

17. Hedeskov CJ (1980) Mechanism of glucose-induced insulin secretion. Physiol Rev 60: 442-509

Received: 27 June 1983

and in revised form: 19 January 1984

Dr. Peter Thams

Department of Biochemistry A

University of Copenhagen

3C Blegdamsvej

DK-2200 Copenhagen N

Denmark 